\title{
Preliminary Results of European Beaver Reintroduction in the Tributary Streams of the Vistula River ${ }^{1}$
}

\author{
Wirgiliusz ŻUROWSKI
}

\begin{abstract}
Żurowski W., 1979: Preliminary results of European beaver reintroduction in the tributary streams of the Vistula River. Acta theriol., 24, 7: 85-91 [With 2 Tables \& 4 Figs.]

In 1977, there were about 254 beaver families in Poland. Most of them inhabit the tributary streams to the Niemen and Pregola Rivers in NE Poland. This situation makes it difficult for the beavers to penetrate into the central part of Poland. In 1976 and 1977, experimental reintroduction of beavers were started, into the basin of the Vistula River. The beavers to be introduced into these new sites were either removed from the free-living population or taken from a beaver farm at Popielno. In a selected site artificial lodges or burrows were prepared. Sixteen pairs of beavers were put in these lodges or burrows, after having received an injection of Combelen $(0.02-0.03 \mathrm{ml} / \mathrm{kg}$ body weight). In places frequented by people, good results were obtained by using beavers from the beaver farm at Popielno.

[Inst. Genet. \& Anim. Breed., Polish Acad. Sci., Res. Stat. Popielno, Poland]
\end{abstract}

\section{INTRODUCTION}

In 1977, in Poland, there were about 254 beavers' (Castor fiber L in nae us, 1758) families, i.e. about 1000 individuals. The majority of them live in the tributary streams of the Niemen and Pregola Rivers, in North-East Poland (Fig. 1). This situation makes the penetration of beavers into the central part of the country difficult. Therefore, the programme of active preservation of this species, including transplantation, was worked out. The programme is realized by the Experimental Station of Polish Academy of Sciences at Popielno, from finances of Polish Hunting Association, in the tributary streams of the Vistula River; and by the Institute of Applied Zoology, Agricultural Academy in Poznan in the tributary streams of the Odra River ( $\mathrm{G} \mathrm{r} \mathrm{a} \mathrm{c} \mathrm{z} \mathrm{y} \mathrm{k,} \mathrm{1977).}$

In 1976 reintroduction of beavers in the north part of Poland was started, mainly into the systems of the Vistula River. Before the realization of this project the methodical research had been made. It concerned living beavers trapping, the way of their introduction into

1 This work was supported by Polish Academy of Sciences within the project 10.2.06. 
new places, and usefulness of animals derived from the farm to the introduction. The results were successful even with few specimens of this so rare and precious species.

\section{MATERIAL AND METHODS}

The 26 wild animals, as well as 7 those taken from the beavers' farm at Popielno, were used for transplantations. The wild beavers were captured in the Suwałki Lake Region, from the most dense and numerous population in Poland (Fig. 1). The active method of trapping was used, in which a trained dog flushed the beavers from their lodge or burrow out to iron snapself cage, laying under water in burrow's outlet. In the cases of bigger rivers or ponds the cages were

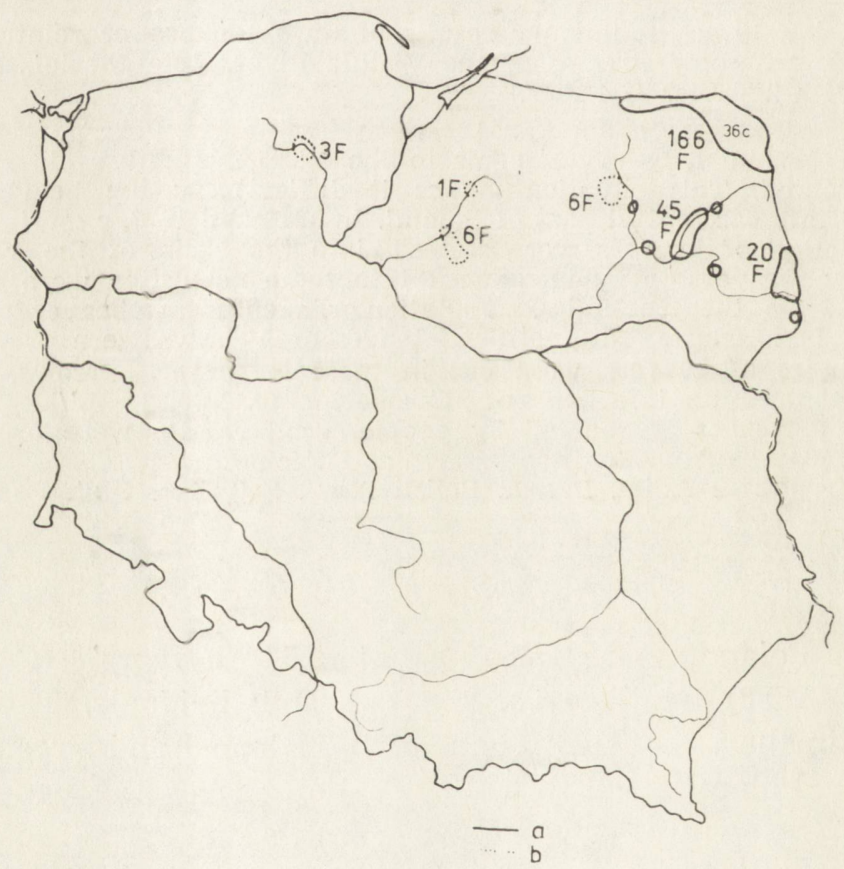

Fig. 1. Distribution range of the wild population European beaver and introduced beavers in basin of Vistula River, in the spring of 1978.

a - Approximate locations of beavers leading a wild existance.

b - Location of beavers artificially introduced by P.A. of Sci.

$\mathrm{F}$ - Numbers of families in particular population.

c - Number of captured individuals.

assisted by a net. The net was made in three layers. Two outside layers were thin, with $3 \mathrm{~cm} \times 3 \mathrm{~cm}$ mesh, and the inside one was thick, with a $30 \mathrm{~cm} \times 30 \mathrm{~cm}$ mesh. The captured animals received intramuscular injection of tranquilizer (Combelen, $0.02-0.03 \mathrm{ml}$ per $1 \mathrm{~kg}$ body weight, according to the size and condition of beaver). After that, the beavers were kept waiting in the transport-cages, in a cool and well aired place, to collect more animals, but not longer than 3 days. They received water and aspen twigs. The groups of collected animals were transported 
to the beaver farm at Popielno, where they were paired and prepared to introductions into the new sites. The pairs were formed from the adult beavers and from young ones weighing not less than $13 \mathrm{~kg}$. Younger animals remained at farm. for a year, or were leaving with their parents. The age of captured beavers was estimated using their weight and exterior. Captures were made in spring, since the time of ice disappearring, till April the 20-th, and in October till the beginning of November. As soon as it was possible they were introduced in the new areas. The introductions' places, rich in woodden food, (aspen, willow, birch) and with pure and deep water were chosen. From three to seven pairs or families were located in the areas of about $20 \mathrm{~km}$ in diameter, with the connected water system. Beavers were placed into the formerly prepared artificial burrows or lodges (Fig. 2). Underwater outlet of lodge was closed with the sticks. An artificial

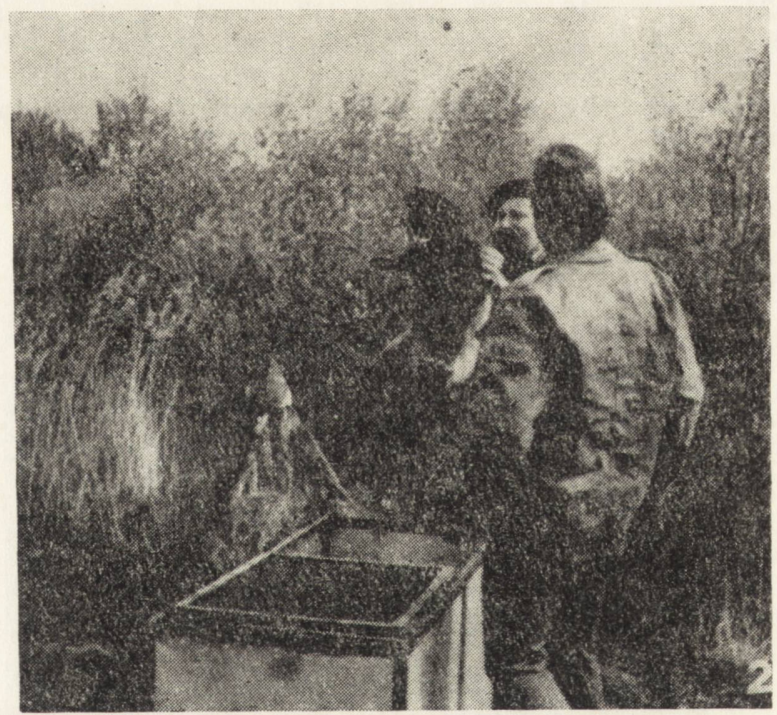

Fig. 2. The beaver is puting in the artificial lodge (the Maraki Bog).

lodge, like a natural one, had a chamber $(80 \times 80 \times 40 \mathrm{~cm}$ in size) above water and the underwater canal about $30 \mathrm{~cm}$ in diameter. In the back side of the lodge or burrow was a hole to put the animals through. After the location of beavers this hole was shut. The animals were under action of Combelen $(0.02-0.03 / \mathrm{kg}$ body weight). Places of introduction were not penned.

In May and June attempts were made to detect the births of the young by tape recordings. The half an hour records were repeated several times in the same nests. They have been made during the day, when the beavers' kitts were active and noisy.

\section{RESULTS}

Results of trapping of beavers are collected in Table 1. The used capture method was very efficient in comparison with other methods (Uhlenhaut et al., 1977). One to one and a half beavers were captured per 1 working day. However, the dog with an exellent smell, 
Table 1

Beaver captures in 1977 and 1978 in Suwałki Region.

\begin{tabular}{|c|c|c|c|c|c|c|c|c|c|c|c|}
\hline \multirow[b]{2}{*}{ 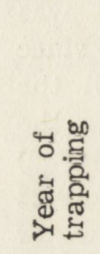 } & \multirow[b]{2}{*}{ 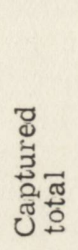 } & \multirow{2}{*}{ 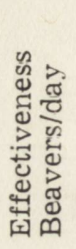 } & \multicolumn{2}{|c|}{ Sex } & \multicolumn{2}{|c|}{ Colour } & \multicolumn{4}{|c|}{$\begin{array}{l}\text { Age of animals } \\
\text { (years) }\end{array}$} & \multirow[b]{2}{*}{ 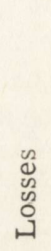 } \\
\hline & & & 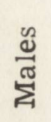 & 胥 & $\begin{array}{l}\frac{y}{d} \\
\frac{\pi}{m} \\
\end{array}$ & $\begin{array}{l}5 \\
\vdots \\
0 \\
\text { m }\end{array}$ & 1 & 2 & 3 & $\frac{\stackrel{n}{ \pm}}{3}$ & \\
\hline 1977 & 21 & 1.0 & 10 & 11 & 11 & 10 & 3 & 4 & 7 & 7 & $2 *$ \\
\hline 1978 & 15 & 1.5 & 6 & 9 & 12 & 3 & 1 & 4 & 2 & 8 & - \\
\hline Total & 36 & & 16 & 20 & 23 & 13 & 4 & 8 & 9 & 15 & 2 \\
\hline Avg. $v$ & $\mathrm{~kg}$ & 1.2 & & & & & 7.6 & 12.4 & 15.8 & 18.1 & \\
\hline
\end{tabular}

* One female, injured by another beaver, died in transportation; one male died in collecting centre.

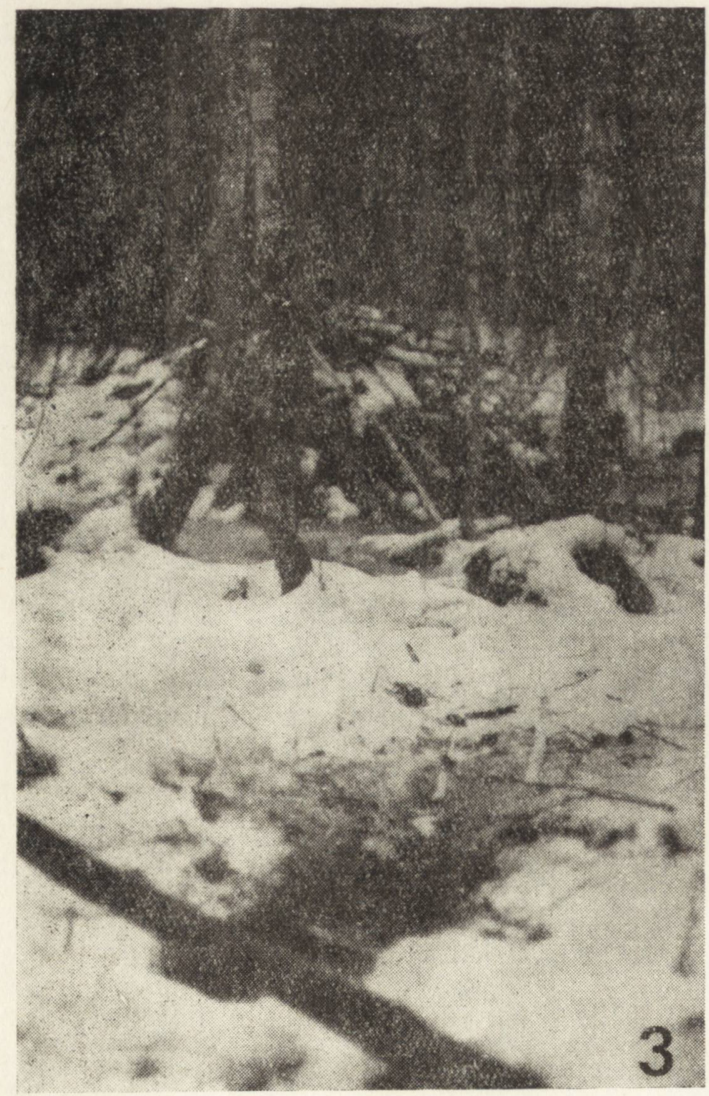

Fig. 3. Beaver's lodge on the river Blankowa Struga, in winter (9 month after the introduction). 
Table 2

Introductions of European beavers in the basin of Vistula River during period 1976-1978.

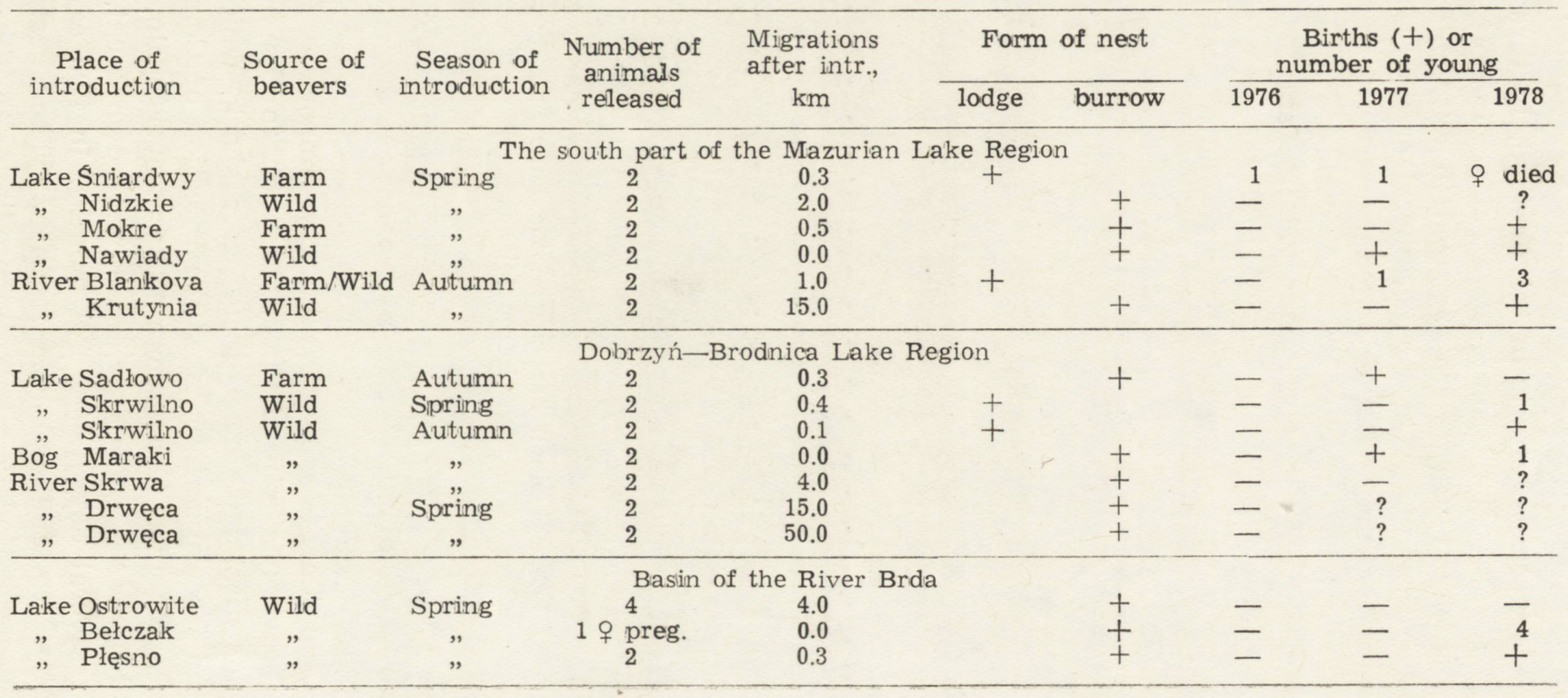


hardworking, barking but not aggressive was needed. There were not observed any negative effects of this method. In three cases, from the same lodges where the beavers were caught in spring, the new ones or the recompleted pairs were captured in autumn or next spring. Captures were conducted in the peripheral or new positions of population. Therefore, among the captured beavers, it was so many alone, immature animals, or pairs without the young.

Results of introductions are collected in Table 2. Sixteen pairs or families of beavers were introduced into the new sites. Three pairs stayed in the release site; seven pairs wandered and settled down not

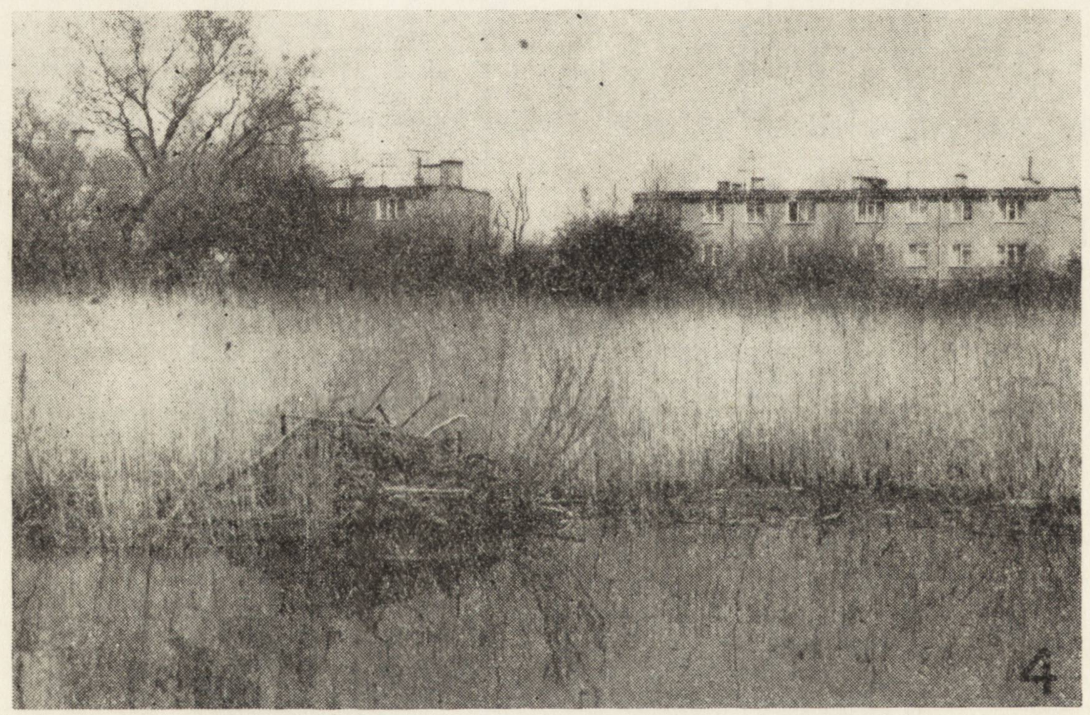

Fig. 4. Beaver's lodge at small harbour on the Lake Sniardwy (2 years after the introductions).

farther than $1 \mathrm{~km}$; three pairs wandered to a distance of no more than $4 \mathrm{~km}$; two pairs, about $15 \mathrm{~km}$; and one pair, about $50 \mathrm{~km}$. The last three pairs were released on bigger streams.

Earlier experiments showed that a very important factor for settling down of beavers is a preliminary adaption to the new environment. The animals must be protected against a shock, which might cause a divorce and far wandering. After the injection of Combelen they were tranquilized for $12-24 \mathrm{hr}$. When they recover again, they respect an artificial lodge as a safe place, with their own scent. They used this nest from several days to several months. In two cases they adopted artificial burrows and remained in them. The beavers which left artificial nests settled down in the proximity of the area planned for them (Fig. 3). Only one pair introduced on the bigger river - Drwęca, 
wandered too far $(50 \mathrm{~km})$. Animals from the farm were successfully introduced in places often troubled by man (Fig. 4).

Beavers' detecting by tape recording was possible in the lodges. It was possible to constate birth of the young and even estimate their number. The beaver kitts' voices have individual differences. The burrows were too extended for this method and only the visual observations, in autumn, could be done to state the presence of young. It was rather difficult to state their number in these cases. The cases of divorce were not observed. The natural loses were not found, but 1 male was killed by a man, and 1 female died poisoned by oil pollution of water. This last pair have been recompleted.

\section{CONCLUSIONS}

1. The used methods of capture and of introduction were efficient. The new populations of beavers can be established with them using not too numerous material.

2. The animals from the farm make possible the introduction of beavers into the places constantly penetrated by men.

\section{REFERENCES}

1. Graczyk R., 1977: Zucht und Wiedereinbürgerung vom Aussterben bedrohter Vögel und Säuger in der VR Polen. Herausgegeben vom Deutschen Bund für Vogelschutz e.V. DBV-VERLAG: $3-15$.

2. Uhlenhaut K., Stubbe M. \& Piechocki R., 1977: Der Lebendfang des Flussbibers Castor fiber L., 1758. Arch. Naturschutz u. Landschaftsforsch., 17-3: 211-222. Berlin.

Accepted, August 10, 1978.

\section{Wirgiliusz ŻUROWSKI}

WSTĘPNE WYNIKI REINTRODUKCJI BOBRA W DORZECZU WISEY

\section{Streszczenie}

W roku 1977 w Polsce było około 254 rodziny bobrów. Większość z nich występowała w północno-wschodniej Polsce, w dorzeczach Niemna i Pregoły (Ryc. 1). W takiej sytuacji bobry mają utrudnioną penetrację do centralnych regionów Polski.

W latach 1976 i 1977 rozpoczęto eksperymentalną reintrodukcję bobrów w basenie Wisły. Introdukowane zwierzęta pochodziły bądź z populacji żyjących na swabodzie (Tabela 1), bądź z hodowlanej fermy w Popielnie. Przy odłowach stosowano injekcję preparatu Combelen $(0.02-0.03 \mathrm{ml} / \mathrm{kg}$ ciężaru ciała). W wybranych miejscach przygotowano sztuczne nory i żeremia. W miejscach tych umieszczono 16 par bobrów (Ryc. 1, Tabela 2). W miejscach często odwiedzanych przez ludzi dobre wyniki osiągnięto zasiedlając bobry pochodzące $\mathrm{z}$ hodowli w Popielnie. 